\title{
Consumption of endophyte-infected fescue seed during the dry period does not decrease milk production in the following lactation
}

\author{
Ransom L. Baldwin VI, ${ }^{*}$ Anthony V. Capuco, ${ }^{* 1}$ Christina M. Evock-Clover, ${ }^{*}$ Paolo Grossi, $\dagger$ \\ Ratan K. Choudhary, $\$ \S^{2}$ Eric S. Vanzant, $\S$ Theodore H. Elsasser, ${ }^{*}$ Giuseppe Bertoni, $\dagger$ Erminio Trevisi, $\dagger$ \\ Glen E. Aiken,\# and Kyle R. McLeod§ \\ *Animal Genomics and Improvement Laboratory, USDA-Agricultural Research Service, Beltsville, MD 20705 \\ †Istituto di Zootecnica, Università Cattolica del Sacro Cuore, I-29100, Piacenza, Italy \\ ‡Department of Animal and Avian Sciences, University of Maryland, College Park 20742 \\ §Department of Animal Sciences, University of Kentucky, Lexington 40546 \\ \#Forage-Animal Production Research Unit, USDA-Agricultural Research Service, Lexington, KY 40506
}

\begin{abstract}
Ergot alkaloids in endophyte-infected grasses inhibit prolactin (PRL) secretion and may reduce milk production of cows consuming these grasses. We investigated the effects of consuming endophyte-infected fescue seed during late lactation and the dry period on mammary growth, differentiation, and milk production. Twenty-four multiparous Holstein cows were randomly assigned to 3 treatment groups. Starting at $90 \pm 4 \mathrm{~d}$ prepartum, cows were fed endophyte-free fescue seed (control; CON), endophyte-free fescue seed plus $3 \times / \mathrm{wk}$ subcutaneous injections of bromocriptine $(0.1 \mathrm{mg} / \mathrm{kg}$ of body weight, positive control; BROMO), or endophyteinfected fescue seed (INF) as $10 \%$ of the diet on an as fed basis. Although milk yield of groups did not differ before treatment, at dry off ( $-60 \mathrm{~d}$ prepartum) INF and BROMO cows produced less milk than CON. Throughout the treatment period, basal concentrations of PRL and the prepartum increase in plasma PRL were reduced in INF and BROMO cows compared with CON cows. Three weeks after the end of treatment, circulating concentrations of PRL were equivalent across groups. In the subsequent lactation milk yield was not decreased; in fact, BROMO cows exhibited a $9 \%$ increase in milk yield relative to CON. Evaluation of mammary tissue during the dry period and the subsequent lactation, by quantitative histology and immunohistochemical analysis of proliferation markers and putative mammary stem or progenitor cell markers, indicated that feeding endophyte-infected fescue
\end{abstract}

\footnotetext{
Received February 5, 2016.

Accepted May 4, 2016.

${ }^{1}$ Corresponding author: tony.capuco@gmail.com

${ }^{2}$ Current address: School of Animal Biotechnology, GADVASU, Ludhiana, Punjab 141004, India.
}

seed did not significantly affect mammary growth and development. Feeding endophyte-infected grasses during the dry period may permit effective utilization of feed resources without compromising milk production in the next lactation.

Key words: ergot alkaloids, fescue toxicosis, prolactin, mammary development, milk yield

\section{INTRODUCTION}

Tall fescue is a common pasture grass throughout much of the United States due to its persistence and drought tolerance. However, animal productivity is often reduced when animals graze on tall fescue grass due to ingestion of ergot alkaloids found in the fungal endophyte-infected plant (Strickland et al., 1993; Aiken and Strickland, 2013). Signs of fescue toxicosis include increased respiration, reduced feed intake, suppressed immune function, decreased weight gain, and decreased milk production.

Utilizing available forage sources is, in some areas, an attractive means to reduce feed costs. Grasses containing endophytes may be increasingly important in the face of climate changes because the symbiosis between plant and endophyte provides increased drought resistance and hardiness to the plant, and endophyte-grass interactions influence forage and pasture sustainability (Gundel et al., 2012). However, the monetary savings that may be gleaned by utilizing predominantly available forages may be negated by reduced milk production due to fescue toxicosis. Of course, the effect of fescue toxicosis is not only relevant to the dairy industry but to the beef industry and other grazing livestock.

Although numerous studies have documented a correlation between consumption of endophyte-infected fescue grass and decreased milk production (Peters et al., 1992; Brown et al., 1993; Aiken and Strickland, 2013), scant literature exists addressing the effect of 
ergot alkaloids on mammary growth and development. By using a synthetic ergot alkaloid that markedly inhibits prolactin (PRL) secretion and by restoring plasma PRL by infusion of the hormone, we previously demonstrated that PRL is important for the final stage of mammary differentiation that occurs during the periparturient period, resulting in decreased milk yield during the first $10 \mathrm{~d}$ after parturition when the experiment was terminated (Akers et al., 1981a,b). Conversely, feeding endophyte-infected tall fescue grass for approximately 1 mo before calving reduced plasma PRL concentrations, but did not significantly affect milk production during the initial 10 wk after calving (Bernard et al., 1993). The quantity of ergot alkaloids consumed was not assessed in the latter study and, thus, we sought to more fully evaluate the effect of consuming endophyte-infected fescue grass on mammary function. Others have implicated PRL as a mediator of photoperiod effects during the dry period on subsequent milk production (Crawford et al., 2015). Elucidation of the cellular and molecular mechanisms by which consumption of endophyte-infected grasses affect mammary gland function should reveal methods to offset or alleviate the detrimental effects of ergot alkaloids on milk production, and thereby enhance animal productivity and profitability. Herein, we address the effect of consuming endophyte-infected fescue seed on milk mammary growth during the dry period and subsequent milk yield.

We hypothesized that consumption of endophyteinfected fescue seed during the dry period would inhibit mammary differentiation, and possibly mammary growth, primarily due to a disruption of PRL stimulation. Because bromocriptine, a synthetic alkaloid, is a dopamine agonist that inhibits the secretion of PRL by the pituitary and decreases circulating concentrations of PRL (Fitzgerald and Cunningham, 1982), we included bromocriptine treatment as a positive control. The objective of our study was to determine the effect of consuming endophyte-infected fescue seed during late lactation and the dry period on mammary development and productivity of the next lactation. To ensure that treatment encompassed the final stage of mammary differentiation, treatment was continued until d 10 of the subsequent lactation.

\section{MATERIALS AND METHODS}

\section{Animals and Dietary Treatments}

Twenty-four multiparous Holstein cows from the Beltsville Agricultural Research Center Dairy (Beltsville, MD) were used in a completely randomized de- sign. An ordered sequence of the 3 treatments was randomly selected and cows were assigned to this repeating sequence in the order of their predicted calving date. The 3 treatments were (1) negative control (CON; n = 9), a diet containing K32 tall fescue seed, certified endophyte-free, added as $10 \%$ of the ration as fed; (2) positive control (BROMO; $\mathrm{n}=7$ ), a diet containing K32 fescue seed, but additionally received subcutaneous injections of the dopamine agonist, bromocriptine (3 times/wk; $13.6 \mathrm{mg} / \mathrm{mL}$ in $90 \%$ ethanol; $0.1 \mathrm{mg} / \mathrm{kg}$ of BW), to inhibit PRL secretion; and (3) endophyteinfected group (INF; $\mathrm{n}=8$ ), a diet containing K31 tall fescue seed, infected with endophyte (Neotyphodium coenophialum), added as $10 \%$ of the ration. Cows were fed twice daily in equal amounts.

Seed was ground through a 1-mm screen (model 3 Wiley Mill, Arthur H. Thomas Co., Philadelphia, PA) and directly incorporated into the normal herd ration for the particular stage of lactation. Treatments began $90 \pm 4 \mathrm{~d}$ (mean $\pm \mathrm{SEM}$ ) before expected calving and continued until $10 \mathrm{~d}$ postpartum to examine direct effects of dietary treatment on mammary growth and cellular differentiation during the last trimester of gestation. Cows were added to the study as they became available (based on predicted calving date). Thus, the actual dates for the initiation and conclusion of treatment application varied across animals, though balanced across treatments. Furthermore, treatments and dry off were initiated during weekdays to facilitate scheduling subsequent biopsy and processing of tissues. Cows were housed in tiestalls for the duration of the study, with daily exercise of at least $3 \mathrm{~h}$. Several days before expected calving, cows were moved to a maternity stall. Throughout the experiment, lighting was maintained at $16 \mathrm{~h}$ of light and $8 \mathrm{~h}$ of dark. Supplemental artificial lighting produced approximately $170 \mathrm{~lx}$ at cow eyelevel.

Endophyte-infected and noninfected fescue seed were purchased as single lots from a commercial seed supplier (Turner Seed Inc., Winchester, KY). Samples of each lot were collected using a bag trier (\#236; Seedboro, Chicago, IL); a minimum of 10 bags were sampled per lot. Samples were subsequently composited within lot, ground through a 1-mm screen (model 3 Wiley Mill; Arthur H. Thomas Co.), and analyzed for ergovaline and ergovalanine content by HPLC florescence using the procedure described by (Aiken et al., 2009). Alkaloid concentrations reported are the total ergovaline and ergovalanine content.

The treatment scheme, biopsy schedule (described below), and collection of milking records are illustrated in Figure 1. All procedures involving animals were approved by the Beltsville Agricultural Research Center Animal Care and Use Committee. 


\section{DMI}

Daily DMI was monitored for each cow beginning on the day of treatment initiation. Cows were fed twice daily in equal amounts. Orts were collected and weighed at the morning feeding and daily DMI were calculated based on the DM of weekly composite samples from feed collected daily. For data analysis, intake values were expressed as a percentage of BW, where BW was each cow's weight on the day that treatment began. Also, DMI analyses were conducted separately for each of 4 phases. Phase 1 represented DMI for the first lactation (d 0 to 26 with respect to treatment initiation). Intake during the dry period was represented by phases 2 and 3 . Phase 2 , representing the early dry phase, included the first $4 \mathrm{wk}$ of the dry phase. Phase 3 included $3 \mathrm{wk}$ before calving for each cow. Thus, phase 2 was standardized relative to days dry, and phase 3 relative to days from calving. The fourth phase represented intake from calving to 1 wk postpartum.

\section{Tissue Samples}

Mammary tissue $(0.5-1 \mathrm{~g})$ was obtained via mammary gland biopsy the week before drying-off $(67 \pm 2 \mathrm{~d}$ before expected parturition), during the dry period (32 $\pm 2 \mathrm{~d}$ before expected parturition) and $10 \mathrm{~d}$ postpartum $( \pm 1 \mathrm{~d})$. Rear quarters were biopsied in all cases; the 10-d sample was obtained from the same quarter as the -67-d sample, but at a different location within the gland. Tissues biopsies were obtained using the biopsy tool and methodology as previously described (Farr et al., 1996; Hale et al., 2003), with an additional step of inserting a sterile teat cannula during the biopsy to promote drainage of blood during the procedure. A portion of the mammary biopsy was fixed in neutral buffered formalin and processed for histological and immunohistochemical analysis (Capuco et al., 2002), and another portion of tissue was immediately snap frozen in liquid nitrogen for gene expression analysis by RNA sequencing (data not presented).

Blood samples were collected once per week, at a time that coincided with $\sim 2 \mathrm{~h}$ after the morning milking, via jugular or tail vein puncture for quantification of plasma PRL by RIA. To evaluate the effect of treatment on the periparturient release of PRL that is associated with initiation of lactation, blood samples were taken every $12 \mathrm{~h}$ from approximately $15 \mathrm{~d}$ prepartum to $3 \mathrm{~d}$ postpartum via a sterile indwelling polyvinyl jugular catheter, or by tail vein puncture in cases of catheter failure. Additional blood samples were obtained at 10, 13, 21, and 28 DIM. Blood samples were collected into heparinized tubes. Samples were then centrifuged $(2,000$ $\times g, 20 \mathrm{~min}, 4^{\circ} \mathrm{C}$ ), plasma collected, and frozen until thawed for double antibody RIA of PRL (Forrest et al., 1980). The intra-assay coefficient of variation was $8 \pm$ $2 \%$ and interassay coefficient of variation was $15 \%$. For data analysis, PRL concentrations were evaluated in each of 3 phases, represented by preparturient weekly samples (phase 1), samples collected to characterize the periparturient PRL surge (15-d prepartum through $3 \mathrm{~d}$ postpartum; phase 2), and postparturient weekly sam-

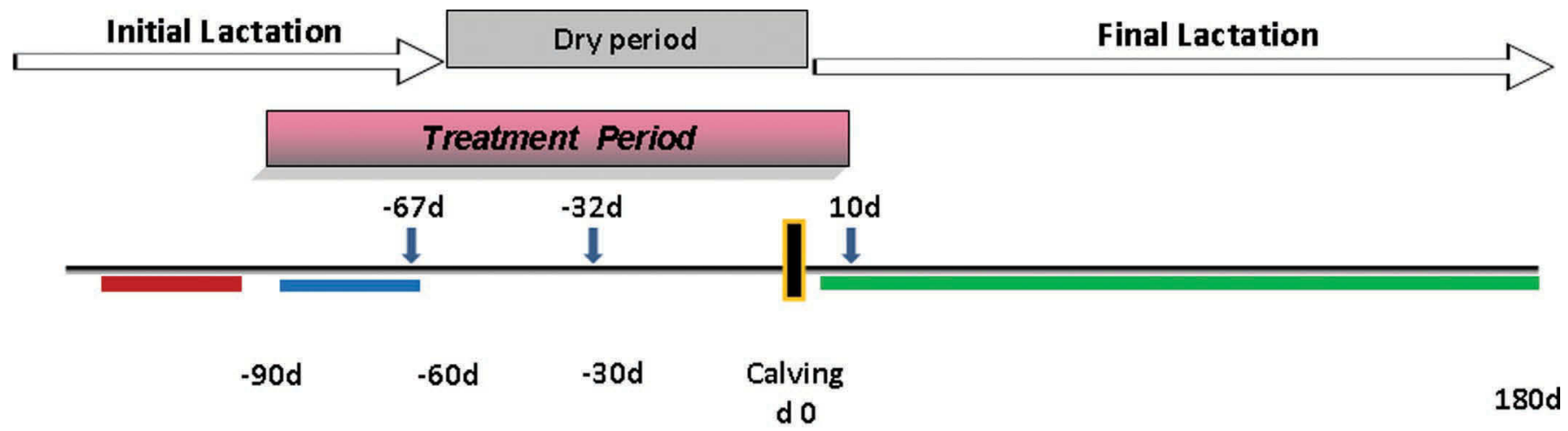

Mammary biopsies: $d-67,-32$ and +10

Milk record (30d) prior to treatment, initial lactation

Milk record (30d) post treatment, initial lactation

\section{Milk record next (final) lactation}

Figure 1. Experimental treatment scheme. Timeline represents days relative to expected calving (prepartum) or actual calving (postpartum). Color version available online. 
ples (phase 3). Prolactin concentrations from phases 1 and 3 were analyzed as serially collected data, whereas the periparturient phase 2 samples were used to determine area under the curve (using GraphPad Prism, v 6.05, GraphPad Software Inc., San Diego, CA) before statistical analysis.

Milk samples were collected at the afternoon milking on d 9 and morning milking on d 10 of lactation, and were analyzed for fat, protein, urea nitrogen, and SCC using Milkoscan/Fossomatic equipment and Fourier transform infrared spectroscopy (Dairy One, Ithaca, NY). Additionally, milk composition was monitored monthly in accordance with DHI protocols.

\section{Calving and Lactation}

Starting 2 wk before the projected calving date, cows were monitored for signs of calving (e.g., restlessness, decreased appetite, vaginal discharge, and leakage of milk). Several days before the predicted calving, cows were moved to a maternity stall.

Cows were milked twice daily at approximately 0700 and $1900 \mathrm{~h}$. Milk weights were recorded electronically at each milking. Response variables for milk yield during the initial lactation included cumulative milk yield from $\mathrm{d}-26$ to -1 (relative to treatment initiation), cumulative milk yield from d 0 to 26 , and the difference between the two. Because treatments and dry off were initiated only during weekdays, to facilitate subsequent biopsies and processing of tissues, a 26- $\mathrm{d}$ treatment period was the minimal duration of treatment and was thus selected as the interval for these measures. For the second lactation, weekly milk production totals for 21 wk were used as the response variable.

\section{Histological Analyses}

Tissue sections, prepared using standard hematoxylin and eosin staining, were used to evaluate the tissue for relative percentages of area occupied by epithelium, lumen, and connective tissue using quantitative morphological analysis (Chalkley, 1943; Akers et al., 1981b). Digital micrographs were overlain with a $10 \times 10$ grid providing for 100 intersections (contact points) per micrograph. Ten micrographs (magnification $320 \times$ ) were evaluated per cow per biopsy time (i.e., 1,000 contact points per cow per biopsy time).

Immunohistochemical staining was used to evaluate mammary growth potential. The Ki67 immunostaining was used to assess the effect of treatment on mammary epithelial cell proliferation, using methods described previously (Capuco et al., 2001). Immunohistochemical staining for potential mammary stem cell (MaSC) or progenitor cell markers was performed as described previously (Choudhary et al., 2013) to determine if treatment induced an alteration in the prevalence of MaSC or progenitor cells within the mammary gland. These markers included nuclear receptor subfamily 5 (NR5A2), cleoporin $153 \mathrm{kDa}$ (NUP153), fibronectin type III domain containing 3B (FNDC3B), Musashi RNA-binding protein 1 (MSI1), aldehyde dehydrogenase 1 family, member A1 (ALDH1), and ubiquitinspecific peptidase 15 (USP15). Sections from biopsies obtained during the dry period and the ensuing lactation were evaluated. Briefly, paraffin sections were dewaxed, hydrated, and then quenched in $3 \% \mathrm{H}_{2} \mathrm{O}_{2}$ in PBS. Antigen retrieval was performed by boiling sections in $10 \mathrm{~m} M$ Tris containing $1 \mathrm{~m} M$ EDTA, $\mathrm{pH}$ 9.0 , for $5 \mathrm{~min}$ followed by cooling for $10 \mathrm{~min}$ at room temperature and $5 \mathrm{~min}$ in running water or microwave heating in $10 \mathrm{~m} M$ citrate buffer, $\mathrm{pH}$ 6.0. Sections were blocked with $2.5 \%$ prediluted horse serum (Vector Labs, Burlingame, CA) or casein (CAS-blockTM, Invitrogen, Carlsbad, CA). Primary antibodies NR5A2, NUP153, MSI1, and USP15 (Abcam Inc., Cambridge, MA) were used at $0.5 \mu \mathrm{g} / \mathrm{mL}$, except for NUP153, which was used at $0.2 \mu \mathrm{g} / \mathrm{mL}$. Both FNDC3B and ALDH1 (Santa Cruz Biotechnology, Santa Cruz, CA) were used at a final concentration of $0.2 \mu \mathrm{g} / \mathrm{mL}$. Sections were incubated with primary antibody for $1 \mathrm{~h}$ (NR5A2) or $2 \mathrm{~h}$ at room temperature. After washing, sections were incubated with horseradish peroxidase-conjugated broad-spectrum secondary antibody (ImmPRESS anti-mouse/ anti-rabbit, Vector Labs). Positively labeled cells were visualized using 3,3'-diaminobenzidine or ImmPACT VIP (Vector Labs), respectively. Slides were washed, counterstained with hematoxylin or methyl green, and mounted in Permaslip (Alban Scientific Inc., St. Louis, $\mathrm{MO})$.

The proportion of epithelial cells that were positive for Ki67 antigen or for each MaSC/progenitor cell marker was evaluated and expressed as a percentage (percent of diaminobenzidine pixels out of diaminobenzidine plus hematoxylin pixels) in the epithelial area using image J (version 1.48; Schneider et al., 2012). Ten digital micrographs of random microscopic fields were photographed at a 320-fold magnification and evaluated.

\section{Statistical Analysis}

For all response variables, a variety of potential covariates were investigated. The general strategy for all covariate analyses was to evaluate both independent- and pooled-slope models for each covariate, and to include in the final model only covariates found to be significantly related to the response variable. In situations in which the independent slope model provided 
the best fit (i.e., the covariate by treatment interaction was significant), treatments were compared at each of 3 values of the covariate (corresponding to the minimum, mean, and maximum of the covariate values across the range of values represented in the data from this experiment). Where those interactive responses were considered to have potential explanatory value for the treatment responses, plots of those responses have been included.

Covariates evaluated for response variables from the first lactation (milk production, DMI) included milk production from the first lactation, before the initiation of treatments (standardized to include 263-d cumulative milk yields for each cow), date at treatment initiation (to account for potential seasonal effects), and DIM at treatment initiation. Of these, prior milk production was the only term that accounted for significant variation in the model. This covariate was also evaluated (and ultimately included) in the models for DMI during the dry phase and second lactation.

For response variables associated with calving and the second lactation (second lactation milk production, PRL response, mammary histological area, cell proliferation, and stem cell markers), the list of evaluated covariates included prior milk production (as above), the interval from treatment initiation to calving (to account for possible differences induced by obligatory estimation of calving dates), and prior lactation length.

Response variables for milk yield during the initial lactation included cumulative milk yield from $\mathrm{d}-26$ to -1 (relative to treatment initiation), cumulative milk yield from d 0 to 26 , and the difference between the two. These variables were analyzed using the GLM procedure of SAS (SAS/STAT software, version 9.3, SAS Institute Inc., Cary, NC) with a model appropriate for a completely randomized design with a covariate. Terms in the final model included treatment and prior milk production. Means were separated with protected $(P<$ $0.05)$ Fisher's least significant difference (LSD). Likewise, stem cell marker prevalence was analyzed with a one-way ANOVA using the GLM procedure of SAS. In this case, the percent of cells labeled for putative stem cell markers were evaluated in a restricted number of cows due to resource constraints. Three to 5 cows were assessed for each marker; although marker prevalence was assessed in each of 2 stages (dry period and second lactation), sample selection did not permit analysis by repeated measures. For all markers, use of the interval from treatment initiation to calving improved the model fit and thus was included as a covariate in the model.

All other response variables were analyzed using the MIXED procedure of SAS, either to allow for appropriate hypothesis testing in the presence of heterogeneous variances (area under the curve for the peripartum PRL surge), to accommodate appropriate modeling of autocovariance for repeated measures (DMI responses, mammary cell proliferation and histological area), or both (pre- and postsurge serial PRL responses). Heterogeneous error variance was detected by Levene's test for each of the PRL responses. In this case, the MIXED procedure in SAS was used, incorporating a repeated statement in which the group option was specified as treatment, as described in SAS [Usage Note 22526: Testing and adjusting for unequal variances (heteroscedasticity); http://support.sas.com/ kb/22/526.html; accessed July 1, 2015]. For all serially measured responses, analysis was conducted using the MIXED procedure in SAS with a model appropriate for repeated measures within a completely randomized design (including covariates where they were significant). The models included terms for treatment, time, and their interaction. Time was specified as a repeated term, with subject specified as animal (treatment). All variance or covariance structures were fit using a firstorder autoregressive model, and the Kenward-Roger method was specified for calculation of denominator degrees of freedom. When treatment by time interactions were significant $(P \leq 0.05)$, Fisher's LSD were used to separate treatment means within each week.

The independent slope model for prior milk production was included as a covariate in the final statistical models for DMI during the first lactation (DMI phase 1), DMI during the first phase of the dry period (DMI phase 2), DMI during the second lactation (DMI phase 4 ), and for the presurge PRL concentrations (PRL phase 1). The common slope model for the treatment initiation to calving interval was included as a covariate in the final statistical model for milk production in the second lactation, and for tissue areas from histological analysis.

\section{RESULTS}

\section{Diets and Intake}

Chemical composition of the feeds was unaffected by seed additions to the basal lactation rations (Table 1). Extra water was added to the formulation of the basal diet in anticipation of the extra DM added by the seed, such that 52 to $54 \%$ DM was attained. No other parameters were affected by the addition of the K31 and K32 fescue seed to the ration at $10 \%$ on an as-fed basis.

During all phases of the experiment (Table 2), feed intake was reduced by the inclusion of infected fescue seed (K31) in the diet as compared with endophyte-free fescue seed (K32). These phases included the conclusion of the initial lactation, the dry period, and the initial 10 
Table 1. Nutrient composition of the experimental diets provided during lactation and dry periods of the study $^{1}$

\begin{tabular}{lccccc}
\hline & \multicolumn{3}{c}{ Diet } \\
\cline { 2 - 3 } & \multicolumn{2}{c}{ Dry } & & \multicolumn{2}{c}{ Lactation } \\
\cline { 2 - 3 } \cline { 5 - 6 } Item & Control & Endophyte & & Control & Endophyte \\
\hline DM (\%) & 52.6 & 52.5 & & 53.3 & 53.2 \\
CP (\%) & 13.2 & 13.0 & & 16.4 & 16.4 \\
Degradable protein (\%) & 70.0 & 71.0 & & 65.5 & 65.5 \\
NE $($ Mcal/kg) & 1.50 & 1.50 & & 1.70 & 1.70 \\
\hline
\end{tabular}

${ }^{1}$ Composition is presented on basis of wet weight, as fed.

$\mathrm{d}$ of the final lactation. On a BW basis, daily intake of ergot alkaloids averaged $8.3,7.9$ to 9.9 , and $7.7 \mu \mathrm{g} / \mathrm{kg}$ of BW for the 3 periods, respectively. By comparison, BROMO cows received doses of bromocriptine, a synthetic alkaloid, which averaged $32 \pm 1.3 \mathrm{mg} / \mathrm{d}$ (mean $\pm \mathrm{SEM})$, or $47 \mu \mathrm{g} / \mathrm{kg}$ of $\mathrm{BW} / \mathrm{d}$. Similar to ingestion of infected-fescue seed, we noted a reduction of feed intake due to BROMO treatment. However, during the treatment period of the final lactation, the numerical reduction in DMI for BROMO versus CON was not significant $(P>0.05)$. During the initial lactation, the reduction in feed intake was more rapid and of greater magnitude in the INF than BROMO cows (Figure 2). Furthermore, for CON cows greater milk production during the initial lactation (before treatment) was associated with greater DMI during the treatment period (initial lactation and early dry period); whereas, for
BROMO or INF cows, increasing levels of prior milk yield were associated with lower DMI during the treatment period.

\section{PRL Concentrations}

Consumption of infected-fescue seed resulted in a marked reduction in concentrations of PRL in the blood (Figure 3). Basal concentrations of PRL (Figure $3 \mathrm{~A}$ ) declined from an average of $27.3 \mathrm{ng} / \mathrm{mL}$ in $\mathrm{CON}$ cows to $3.6 \mathrm{ng} / \mathrm{mL}$ in INF cows. Similarly, circulating concentrations of PRL in plasma of cows in the positive control group (BROMO) were reduced to $4.3 \mathrm{ng} /$ $\mathrm{mL}$, on average. Thus, basal concentrations of PRL in plasma of INF and BROMO groups were reduced 85 to $90 \%$ relative to $\mathrm{CON}$. In addition to basal concentrations, the periparturient surge in concentration of

Table 2. Dry matter and ergot alkaloid intake by cows on experimental diets provided during all phases of the study

\begin{tabular}{|c|c|c|c|c|c|c|}
\hline Phase $^{1}$ & Item & \multicolumn{3}{|c|}{ Treatment $^{2}$} & SEM & $P$-value \\
\hline \multirow[t]{3}{*}{ Initial lactation } & $\mathrm{DM}(\mathrm{kg} / \mathrm{d})$ & $22.3^{\mathrm{a}}$ & $18.8^{\mathrm{b}}$ & $10.0^{\mathrm{b}}$ & 1.07 & $<0.01$ \\
\hline & Alkaloids $^{3}(\mathrm{mg} / \mathrm{d})$ & 0 & 0 & 5.3 & 0.69 & - \\
\hline & Alkaloids ( $\mu \mathrm{g} / \mathrm{kg}$ of $\mathrm{BW}$ per day) & 0 & 0 & 8.3 & 1.11 & - \\
\hline Dry, first $28 \mathrm{~d}$ & $\mathrm{DM}(\mathrm{kg} / \mathrm{d})$ & $14.7^{\mathrm{a}}$ & $13.1^{\mathrm{b}}$ & $10.1^{\mathrm{c}}$ & 0.54 & $<0.01$ \\
\hline \multirow[t]{4}{*}{ Dry, last $21 \mathrm{~d}$} & $\mathrm{DM}(\mathrm{kg} / \mathrm{d})$ & $13.0^{\mathrm{a}}$ & $9.4^{\mathrm{b}}$ & $8.5^{\mathrm{b}}$ & 0.93 & $<0.01$ \\
\hline & $\mathrm{DM}(\% \mathrm{BW})$ & $1.91^{\mathrm{a}}$ & $1.29^{\mathrm{b}}$ & $1.27^{\mathrm{b}}$ & 0.14 & $<0.01$ \\
\hline & Alkaloids (mg/d) & 0 & 0 & 5.4 & 0.41 & - \\
\hline & Alkaloids $(\mu \mathrm{g} / \mathrm{kg}$ of BW per day) & 0 & 0 & 7.9 & 0.57 & - \\
\hline \multirow[t]{2}{*}{ Final lactation } & $\mathrm{DM}(\mathrm{kg} / \mathrm{d})$ & $15.2^{\mathrm{a}}$ & $15.4^{\mathrm{a}}$ & $7.8^{\mathrm{b}}$ & 1.35 & 0.04 \\
\hline & $\mathrm{DM}(\% \mathrm{BW})$ & $2.26^{\mathrm{a}}$ & $2.12^{\mathrm{a}}$ & $1.17^{\mathrm{b}}$ & 0.20 & 0.02 \\
\hline
\end{tabular}

\footnotetext{
${ }^{\mathrm{a}-\mathrm{c}}$ Within rows, means without common superscripts differ at $P<0.05$.

${ }^{1}$ Phases of the experiment were the initial lactation, dry period and the final lactation (10 DIM). For these analyses, the dry period was subdivided into early and late phases.

${ }^{2} \mathrm{CON}=$ control; INF $=$ infected-fescue seed; BROMO $=$ bromocriptine.

${ }^{3}$ Alkaloid intake was calculated based on feed intake and the total ergovaline and ergovalanine content of the feed assayed. Dose of bromocriptine, a synthetic alkaloid, averaged $32 \pm 1.3 \mathrm{mg} / \mathrm{d}$ or $47 \mu \mathrm{g} / \mathrm{kg}$ of BW per day.
} 

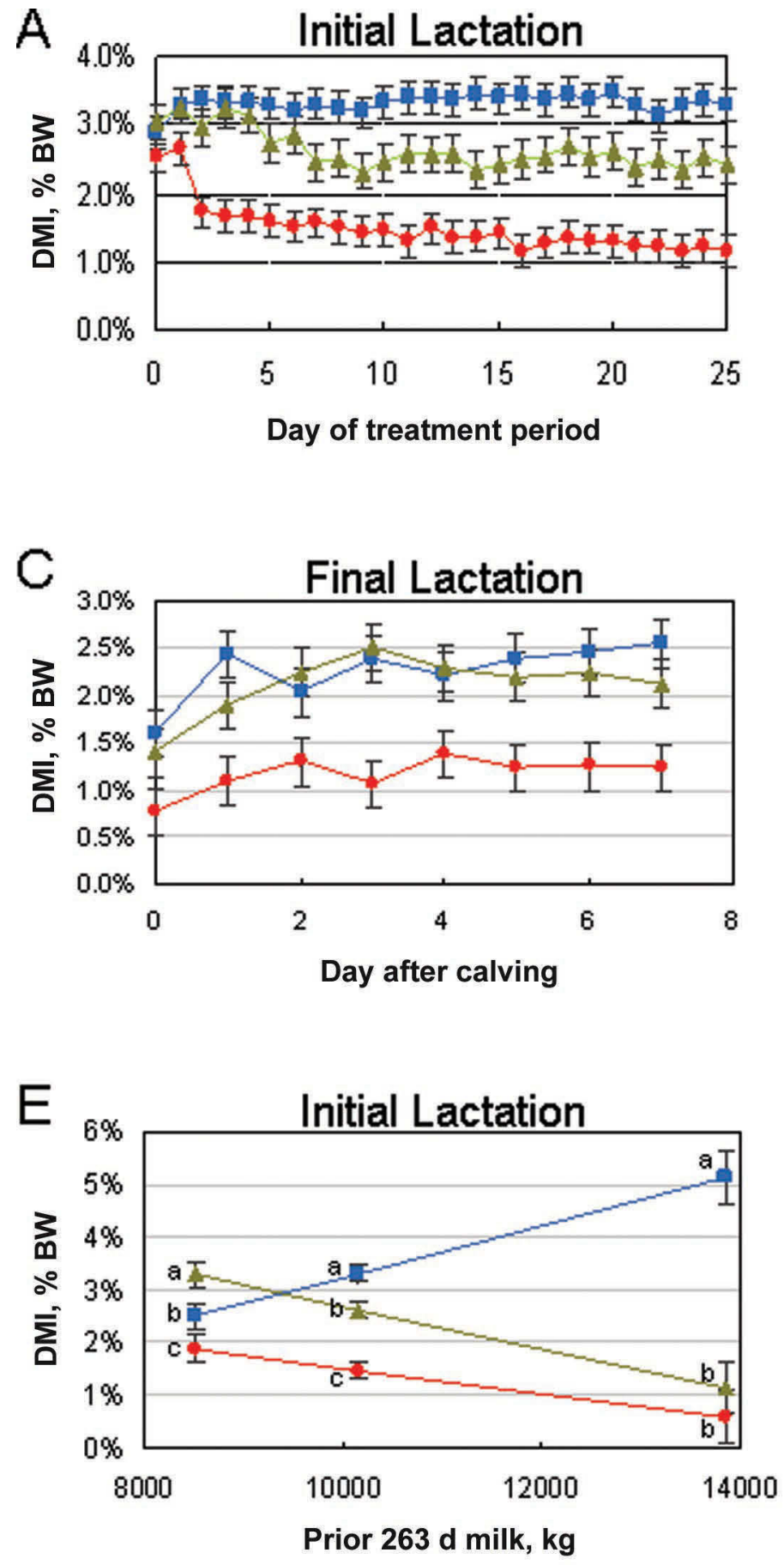
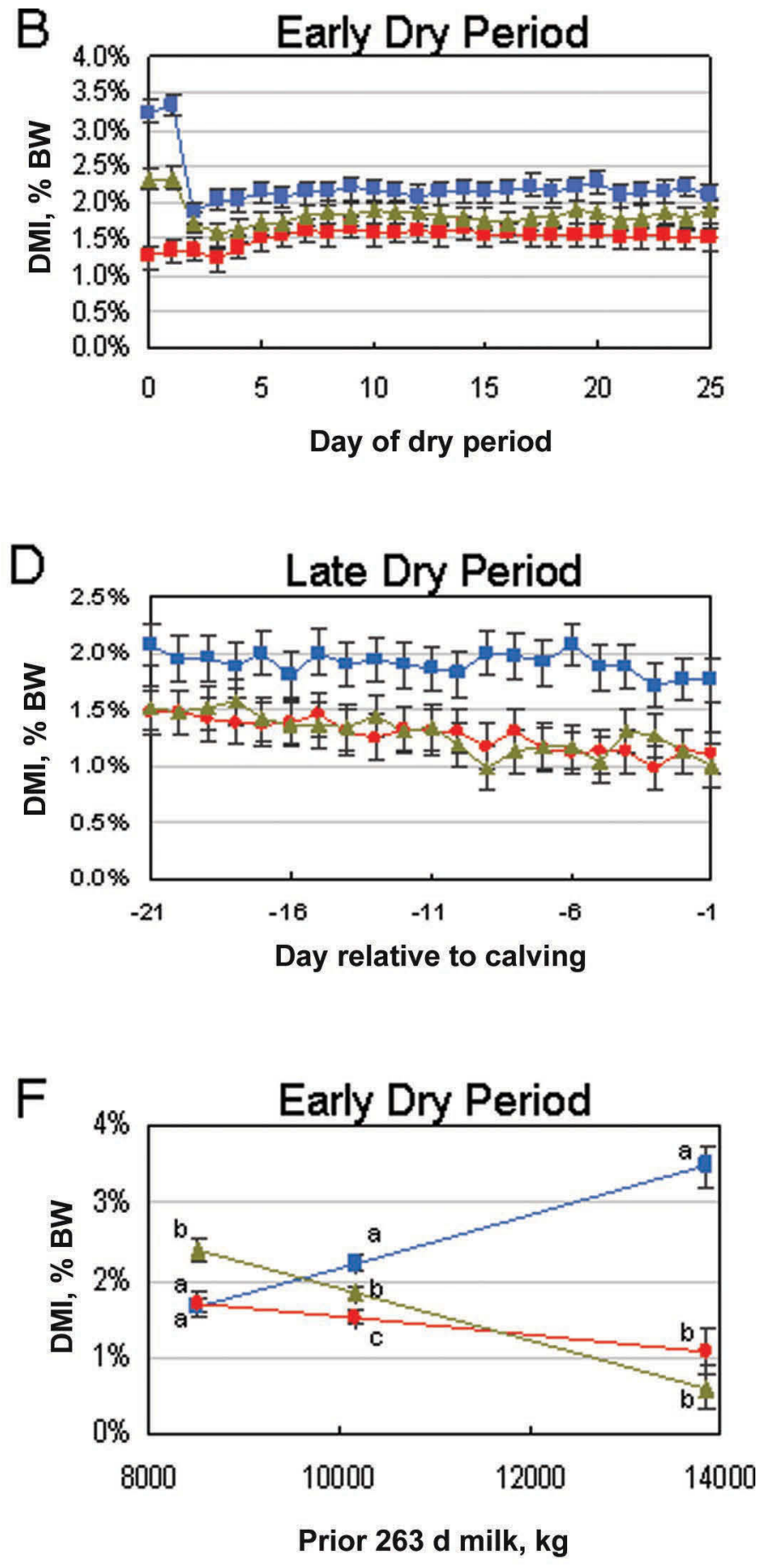

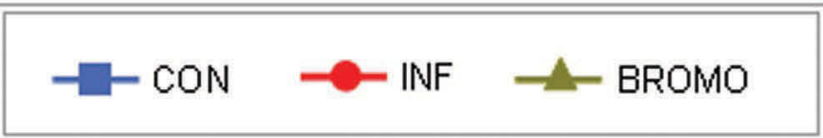

Figure 2. Dry matter intake (mean \pm SEM) during different phases of the experiment and the relationship to prior milk yield. Time course of DMI during initial lactation (A), early (C), and late (D) phases of the dry period, and the treatment period (10 d) of the final lactation (B). Panels E and $\mathrm{F}$ illustrate the effects of prior milk production (fit as a covariate) when it interacted $(P<0.01)$ with treatment. Letters (a-c) denote comparisons among treatments at the minimum, mean, and maximum level of the covariate. Within each level of the covariate, treatment means with unlike letters differ $(P<0.05)$. Color version available online. 
PRL in plasma was reduced in INF and BROMO cows, as compared with $\mathrm{CON}$, by 63 and $95 \%$, respectively (Figure 3B).

\section{Mammary Growth}

Consumption of endophyte-infected fescue seed had no discernible effect on mammary growth at the times evaluated (-32 and $10 \mathrm{~d}$ ). The Ki67 nuclear proliferation antigen was used as a marker for cell proliferation. Within a given physiological stage, the percentage of epithelial cells that were Ki67-positive was equivalent across all treatments (Table 3 ). Cell proliferation was low during lactation and higher during the dry period. Our evaluation of the effect of treatment on activity of MaSC or progenitor cells was based upon expression of several potential markers for these cells. As observed with expression of Ki67 antigen, immunostaining for these potential MaSC or progenitor markers was equivalent across treatments (Table 3). Greater antigen expression was observed during the dry period for NR5A2 and NUP153, whereas greater expression was observed
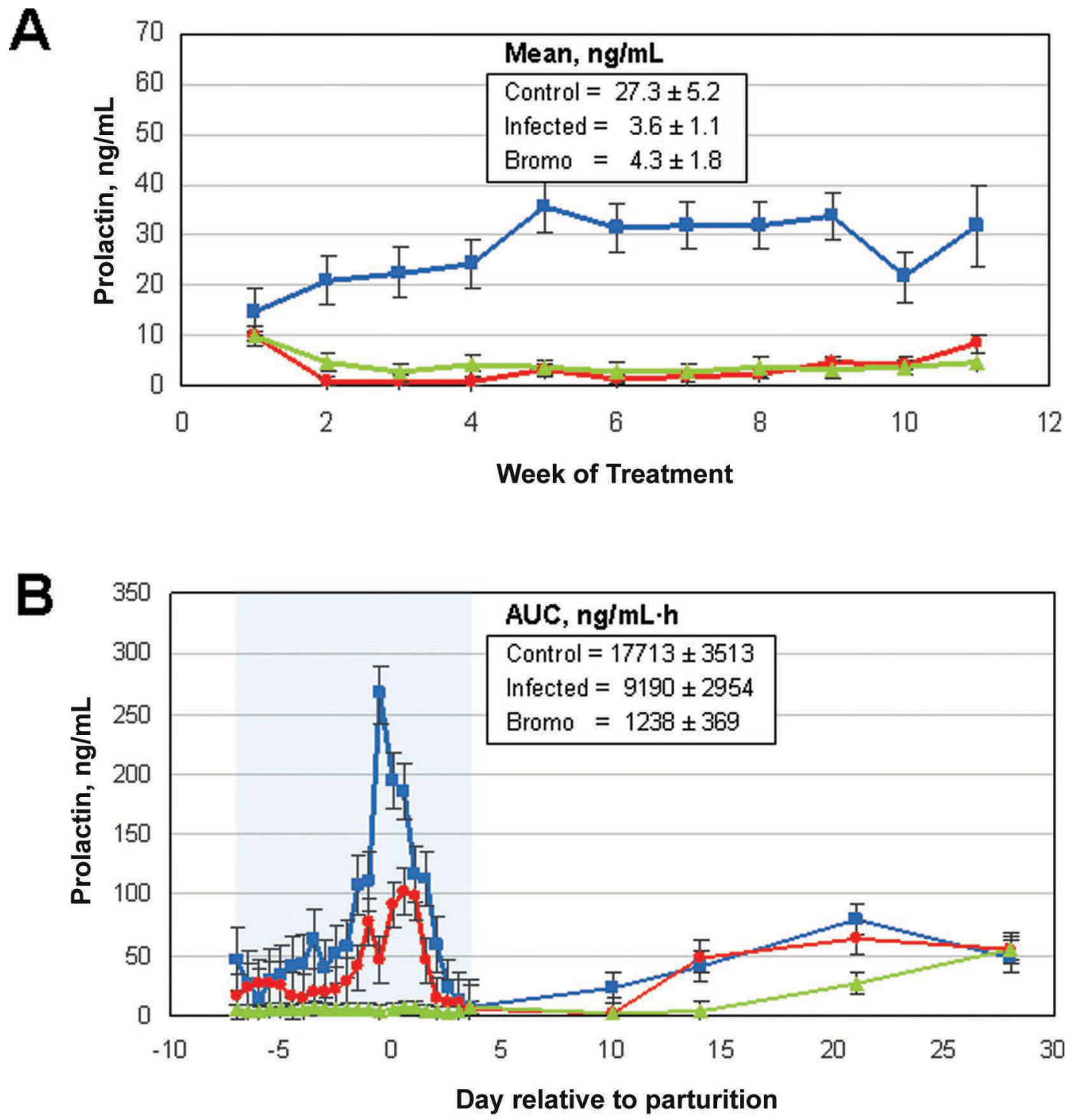

$\rightarrow-\mathrm{CON} \rightarrow-\mathrm{NF} \longrightarrow \mathrm{BROMO}$

Figure 3. Prolactin (PRL) concentrations in plasma. Mean concentrations of PRL in plasma ( \pm SEM) during the treatment period before calving (A) and during the periparturient and postcalving periods (B) are presented. Treatment means for basal PRL concentrations and area under the curve (AUC) for the periparturient PRL surge (shaded area) are provided for control (CON), infected-fescue seed (INF), and bromocriptine (BROMO) treatment groups. Color version available online. 
Table 3. Cell proliferation and expression of mammary stem cell markers ${ }^{1}$

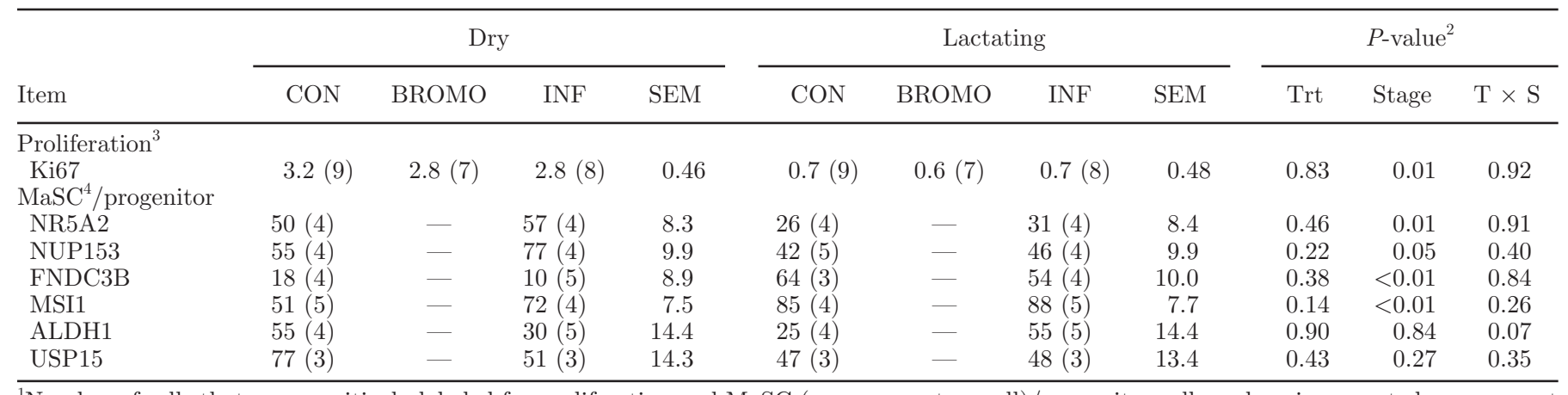

${ }^{1}$ Number of cells that were positively labeled for proliferation and MaSC (mammary stem cell)/progenitor cell markers is presented as a percent of total mammary epithelial cells evaluated. Number of cows evaluated is indicated in parentheses. CON $=$ control; INF $=$ infected-fescue seed; $\mathrm{BROMO}=$ bromocriptine.

${ }^{2}$ Signficance for treatment (Trt), stage (dry or final lactation), and treatment by stage interaction (TxS).

${ }^{3}$ Effect of treatment on proliferation of mammary epithelium was assessed by Ki67 immunohistochemical labeling.

${ }^{4}$ Effect of treatment on MaSC/progenitor cell number was evaluated by immunohistochemical labeling for antigens that have been associated with bovine MaSC/progenitor cells (Choudhary et al., 2013). Only tissues from CON and INF cows were evaluated for expression of MaSC/ progenitor cell markers. NR5A2 = nuclear receptor subfamily 5, group A, member 2; NUP153 = nucleoporin $153 \mathrm{kDa}$; FNDC3B = fibronectin type III domain containing 3B; MSI1 = Musashi RNA-binding protein 1; ALDH1 = aldehyde dehydrogenase 1 family, member A1; USP15 = ubiquitin-specific peptidase 15 .

during lactation for FNDC3B and MSI1. No treatment or stage effect was evident for ALDH1 or USP15.

Quantitative analysis of mammary histology revealed essentially no change in the cellular composition of the tissue during the dry period and final lactation (Figure 4). The percentage of tissue area occupied by epithe- lium averaged $33 \pm 2.1 \%$ (mean $\pm \mathrm{SEM}$ ) across treatment and physiological state. Although no significant treatment effects were noted, we found a significant stage effect for stromal and luminal area $(P<0.01)$. The percentage of tissue area occupied by stroma was $52.5 \pm 2.6$ and $42.3 \pm 2.8 \%$ during the dry period and

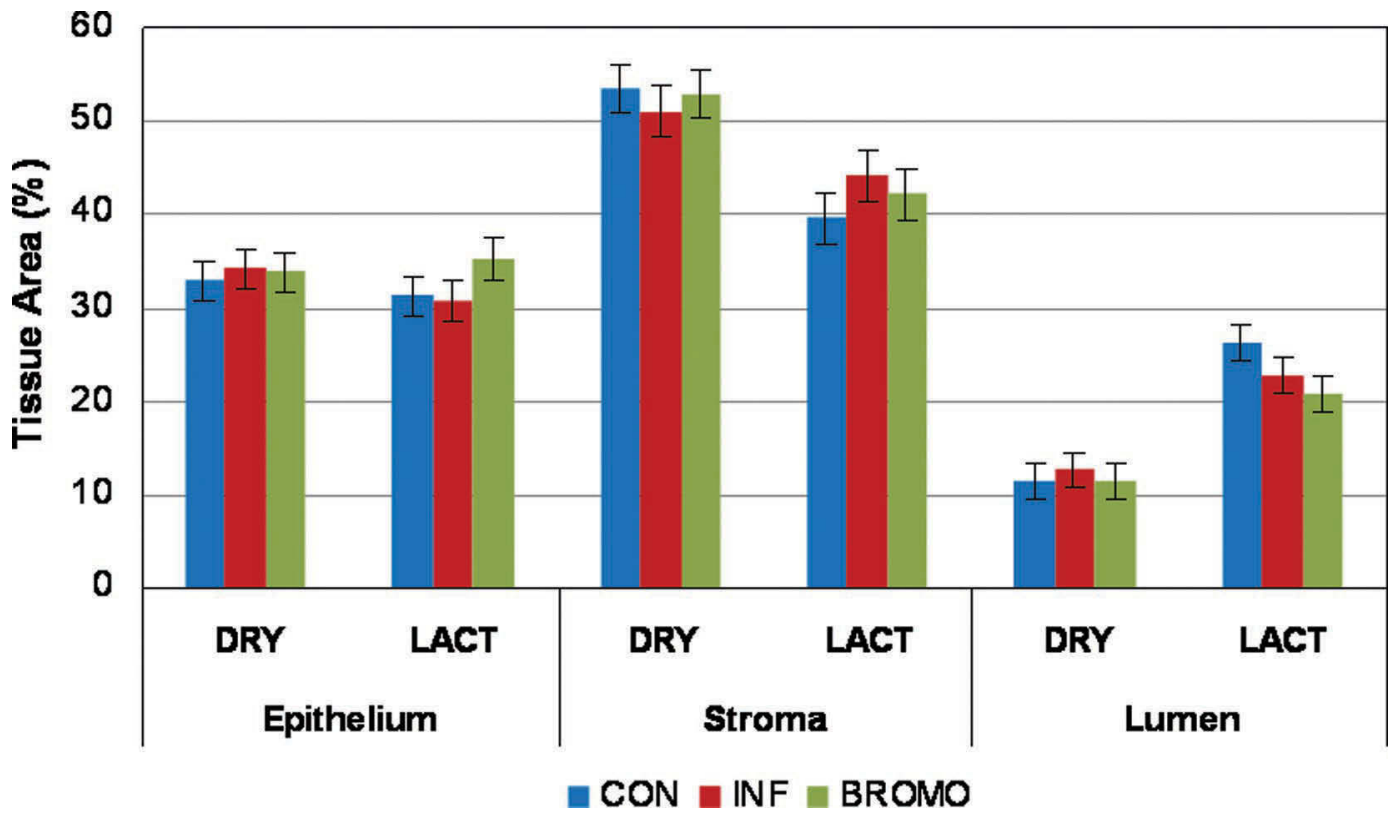

Figure 4. Mammary histological area occupied (mean \pm SEM) by epithelium, stroma, and lumen at $32 \mathrm{~d}$ before expected calving (DRY) and d 10 of the final lactation (LACT). Day 10 of lactation was the final day of treatment. Treatment effects were adjusted for interval from treatment initiation to calving. Treatment was nonsignificant $(P>0.45)$ for all parameters evaluated. Stage was nonsignificant for epithelium $(P=$ $0.45)$ and significant $(P<0.01)$ for percent stroma and percent lumen. Tissues from all biopsies were analyzed [9, 8 , and 7 for control $(\mathrm{CON})$, infected-fescue seed (INF), and bromocriptine (BROMO) cows, respectively]. Color version available online. 
lactation, respectively. The percentage of tissue area occupied by alveolar lumen was $11.9 \pm 1.9$ and $23.2 \pm$ $2.0 \%$ during the dry period and lactation, respectively.

\section{Milk Production}

Overall, consumption of endophyte-infected fescue seed and treatment with bromocriptine each reduced milk yield during the initial lactation, but milk production was not impaired during the subsequent lactation. We observed an initial decrease during the treatment period (until d 10) of the final lactation, after which milk yield of BROMO cows exceeded that of CON for the remainder of the lactation (Figure 5).

Cows in all groups produced equivalent $(P=0.40)$ quantities of milk for the period before the initiation of treatment during the first lactation (Figure 5A), averaging $783 \pm 64 \mathrm{~kg} / 26 \mathrm{~d}(30.1 \pm 2.4 \mathrm{~kg} / \mathrm{d})$. During the treatment period, INF and BROMO cows averaged 14.9 and $16.3 \mathrm{~kg} / \mathrm{d}$, respectively, and CON cows averaged $24.2 \mathrm{~kg} / \mathrm{d}(\mathrm{SEM}=3.0 \mathrm{~kg} / \mathrm{d})$. Analyzed as the change in milk yield from the pretreatment period to the treatment period, milk production was clearly impaired in INF and BROMO cows compared with CON $(P<0.01$, Table 4$)$. The decline in milk yield attributed to treatment from the yield before initiation of treatment was 151,463 , and $294 \mathrm{~kg}$ for CON, INF, and BROMO cows, respectively, over $26 \mathrm{~d}(P<0.01$; Table 4). Because milk production during the pretreatment period significantly influenced milk yield during the treatment period, it was used as a covariate in the analysis. Although DMI during the treatment period significantly influenced milk yield, it was subsumed into the treatment effect rather than being used as a covariate in the analysis.

During the final lactation (Figure 5B), we noted a significant effect of week of lactation $(P=0.01)$ and a treatment by week interaction $(P=0.01)$ on milk yield. During the first $10 \mathrm{~d}$, when cows were still being treated, milk yield was approximately $30 \%$ lower in the INF and BROMO groups than the CON group $(P<$ $0.01 ; P=0.06$, respectively). Milk composition did not differ among treatments at this time (Table 5). After termination of treatment, milk yield of the BROMO group was approximately $9 \%$ greater than that of CON $(P<0.05$, wk 14-21). Milk yield of INF cows was numerically greater than that of CON during this same period, but did not achieve statistical significance $(P$ $>0.1$ ). Additional analyses (Wood, 1967; Wood, 1969) demonstrated that milk curve parameters did not differ among the 3 treatment groups. Based on monthly DHI analyses, milk composition during the final lactation did not differ among treatment groups (data not shown).
Although animal numbers were insufficient to evaluate reproductive performance, gestation length did not differ between groups (mean \pm SE: $274 \pm 3,274 \pm$ 1 , and $274 \pm 2 \mathrm{~d}$ for CON, INF, and BROMO, respectively). No treatment-related health disorders were noted throughout the study.

\section{DISCUSSION}

Our study confirms and extends extensive data and field observations indicating that consumption of endophyte-infected grasses impairs an existing lactation (Peters et al., 1992); additionally, we tested the hypothesis that consumption of endophyte-infected seed during the dry period reduces mammary development, which results in decreased milk yield during the ensuing lactation. We demonstrated feeding endophyte-infected seed during the dry period did not inhibit mammary development and did not reduce subsequent milk production, and therefore reject the hypothesis.

Feed intake by INF cows on the current study equated to consumption of ergot alkaloids at quantities consistent with doses shown previously to cause toxicosis in grazing cattle (Stamm et al., 1994; Aiken et al., 2007). However, because the predominance of ergot alkaloids are localized in the seed head, ergot consumption by grazing cattle is also influenced by such factors as maturity of the grass, cultivar, endophyte, and grazing selectivity and will accordingly be more variable under field conditions than that in the current study.

\section{Initial Lactation}

During the initial lactation, consumption of endophyte-infected seed and treatment with bromocriptine caused a significant reduction in milk production. Because treatment was initiated during the final month of lactation, milk yield decreased significantly in all groups, but we observed a decrease in milk yield of INF cows that was approximately 3 times that of CON cows. Similarly, milk yield of BROMO cows declined twice as much as that of $\mathrm{CON}$ cows. The result was that milk yields of INF and BROMO cows were 62 to $67 \%$ of CON cows. This decrease in milk production was partially explained by a decline in feed consumption in the treatment groups.

Dry matter intake was reduced in both INF and BROMO cows, with the reduction being more rapid and of greater magnitude in the INF cows. Whereas diet palatability issues may account for the greater reduction in DMI in INF versus BROMO cows, the magnitude and kinetics of these responses were undoubtedly a function of the concentration of ergot alkaloids in the seed and the concentration and injection 
A
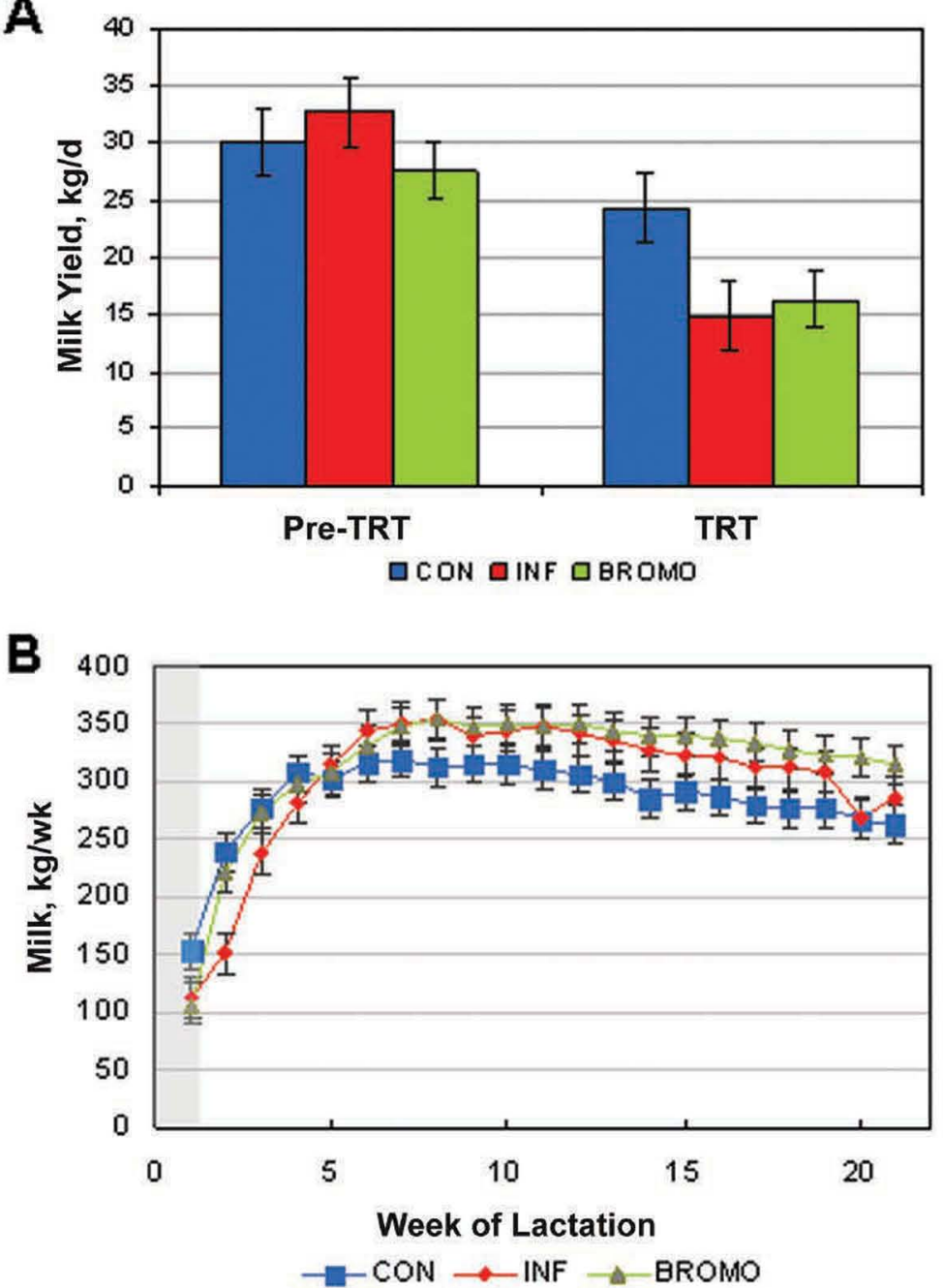

\begin{tabular}{|c|c|c|c|c|c|c|c|}
\hline \multicolumn{8}{|c|}{$P$-values associated with Figure $5 \mathrm{~B}$} \\
\hline Wk & $\begin{array}{l}\text { CON vs } \\
\text { BROMO }\end{array}$ & $\begin{array}{l}\text { CON } v s \\
\text { INF }\end{array}$ & $\begin{array}{l}\text { BROMO vs } \\
\text { INF }\end{array}$ & $\mathrm{Wk}$ & $\begin{array}{l}\text { CON vs } \\
\text { BROMO }\end{array}$ & $\begin{array}{l}\mathrm{CON} v s \\
\text { INF }\end{array}$ & $\begin{array}{l}\text { BROMO vs } \\
\text { INF }\end{array}$ \\
\hline 1 & 0058 & 0083 & 0818 & 12 & 007 & 0.147 & 0.706 \\
\hline 2 & 0.430 & 0000 & 0007 & 13 & 0.073 & $0.12 \theta$ & 0.734 \\
\hline 3 & 0840 & 0087 & 0.158 & 14 & 0.031 & 0079 & 0.532 \\
\hline 4 & 0.669 & 0274 & 0.542 & 15 & 0.048 & 0.17 & 0.494 \\
\hline 5 & 0.797 & 0579 & 0.787 & 16 & 0041 & 0.156 & 0.496 \\
\hline 6 & 0.528 & 0232 & 0613 & 17 & 0.030 & 0.179 & 0374 \\
\hline 7 & 0237 & 0.187 & 0933 & 18 & 0039 & 0.132 & 0530 \\
\hline 8 & 0084 & 0080 & 0961 & 19 & 0061 & 0.166 & 0588 \\
\hline 9 & 0.187 & 0302 & 0.745 & 20 & 0.031 & 0969 & 0.038 \\
\hline 10 & 0.144 & 0200 & 0810 & 21 & 0036 & 0337 & 0240 \\
\hline 11 & 0.124 & 0.109 & 0999 & & & & \\
\hline
\end{tabular}

Figure 5. Milk yield during the initial lactation and the lactation following treatment. Panel A summarizes average milk yields $( \pm$ SEM) during the $26 \mathrm{~d}$ before treatment and $26 \mathrm{~d}$ of treatment during the initial lactation. Panel B summarizes average milk yields ( \pm SEM) during 21 wk of the final lactation. Treatment was continued for the initial $10 \mathrm{~d}$ of lactation (shaded area). CON $=$ control; INF $=$ infected-fescue seed; $\mathrm{BROMO}=$ bromocriptine. Color version available online. 
Table 4. Effect of treatment on milk yield during the initial lactation

\begin{tabular}{|c|c|c|c|c|c|}
\hline Milk yield & \multicolumn{3}{|c|}{ Treatment $^{1}$} & $\mathrm{SEM}^{2}$ & $P$-value \\
\hline $\begin{array}{l}\text { Milk yield, } 26 \mathrm{~d} \text { before treatment }(\mathrm{kg}) \\
\text { Milk yield, } 26 \mathrm{~d} \text { of treatment }(\mathrm{kg}) \\
\text { Change in cumulative milk yield, } 26 \mathrm{~d} \text { prior through } 26 \text { d posttreatment }^{3}(\mathrm{~kg})\end{array}$ & $\begin{array}{r}781 \\
630 \\
-151^{\mathrm{a}}\end{array}$ & $\begin{aligned} & 717 \\
& 423 \\
&-294^{\mathrm{b}}\end{aligned}$ & $\begin{array}{r}850 \\
387 \\
-463^{\mathrm{c}}\end{array}$ & $\begin{array}{l}63.7 \\
77.3 \\
35.5\end{array}$ & $\begin{array}{r}0.40 \\
0.06 \\
<0.01\end{array}$ \\
\hline
\end{tabular}

scheme for BROMO treatment. The observed reduction in DMI observed with BROMO reinforces the concept that the associated reduction in DMI with INF is not a confounding factor, but rather a causative pathway or mechanism for the reduction in milk production. To assess the extent to which treatment-induced alterations in DMI affected milk yield in our study, we evaluated the variation with and without covariates fit to the model and consequently estimated the percent of variation that is accounted for by each. These analyses indicated that a large part of the overall treatment effect was due to differences in DMI (Table 6). Further, the calculations indicate that approximately $45 \%$ of the reduction in milk yield due to treatment can be explained by effects on DMI.

It is noteworthy that the highest-yielding control cows consumed the most feed during the initial lactation and early dry period, whereas cows consuming INF and BROMO did not adjust intake in accordance with milk production. Although no health issues were noted and with time the cows adjusted their intake, their reduced DMI, relative to CON, during late lactation, and the dry period may predispose these cows to metabolic disorders in the next lactation.

\section{Mammary Development}

Others have addressed the negative effect of decreased PRL on milk production (Lacasse et al., 2012) and on differentiation of mammary epithelial cells (Akers et al., 1981a,b) in dairy cows. As anticipated, we observed a significant decrease in basal concentrations of PRL in plasma throughout the treatment period, as well as a reduction in the periparturient surge in plasma PRL. The latter is important for the final stage of lactogenesis and the rapid initiation of copious milk secretion (Akers et al., 1981a,b). Despite a significant decrease in concentration of PRL in the plasma, we did not observe an effect of treatment on mammary development in INF or BROMO cows. Further, using sections prepared from paraffin-embedded tissue samples, we were unable to document an alteration in differentiation of mammary epithelial cells, as noted previously using the greater resolution afforded by plastic tissue sections (Akers et al., 1981b).

Proliferation of mammary epithelial cells was equivalent across treatments at all times evaluated. We employed the Ki67 nuclear proliferation antigen as a marker for mammary cell proliferation (Capuco et al., 2001, 2002). As expected, cell proliferation was low during lactation (Capuco et al., 2001; Finucane et al., 2008) and higher during the dry period, when extensive mammary growth and cell turnover occurs (Capuco et al., 1997; Wall et al., 2005; Capuco and Ellis, 2013). However, within a given physiological stage, the percentage of epithelial cells that were Ki67-positive was equivalent across all treatments. The lack of effect of treatment on cell proliferation was supported by quan-

Table 5. Milk composition during final lactation ${ }^{1}$

\begin{tabular}{lcccc}
\hline & \multicolumn{3}{c}{ Treatment $^{2}$} \\
\cline { 2 - 4 } Item & CON & BROMO & INF & SD \\
\hline Fat $(\%)$ & 4.48 & 3.95 & 4.57 & 2.47 \\
Protein (\%) & 3.58 & 3.40 & 3.36 & 0.42 \\
MUN (mg/dL) & 13.8 & 15.0 & 12.1 & 3.6 \\
SCC $(\times 1,000)$ & 239 & 215 & 163 & 171 \\
\hline${ }^{1}$ Milk composition was assessed on d 9 to 10 of the final lactation. Milk composition was unaffected $(P>0.05)$ \\
by treatment during pregnancy. \\
${ }^{2}$ CON = control; INF = infected-fescue seed; BROMO = bromocriptine.
\end{tabular}


Table 6. Contribution of covariates to variation in milk yield during treatment period of initial lactation

\begin{tabular}{lc}
\hline Covariate & $\begin{array}{c}\text { Percent of variation } \\
\text { accounted for } \\
\text { by treatment }\end{array}$ \\
\hline None & 65.5 \\
Milk yield during pretreatment period & 70.5 \\
Seed intake & 32.2 \\
Deed intake and milk yield during pretreatment period & 37.7 \\
DMI during treatment period & 30.7 \\
\hline
\end{tabular}

titative histological analysis, which indicated that the tissue volume occupied by mammary epithelium was not influenced by treatment. A reduced percentage of tissue volume occupied by stroma and more occupied by lumen in lactating versus dry mammary tissue reflects the expansion of mammary alveoli, due to copious milk synthesis evident at 10 DIM. Similarly, the area occupied by lumen in mammary tissue of lactating CON was numerically greater than that in BROMO or INF cows. Although this was not statistically demonstrable, it is in accordance with the relative milk yields of these groups. Finally, there appeared to be no effect of treatment on MaSC or progenitor cells, the cells that are pivotal for mammary growth and cell turnover, in that expression of potential MaSC or progenitor cell markers (Choudhary and Capuco, 2012; Choudhary et al., 2013) were equivalent across treatments. The proportion of cells expressing these markers was greater than that expected for MaSC, and suggests that the markers detected a large number of progenitor cells. Furthermore, a notable increase in the proportion of epithelial cells expressing MSI1 and FNDC3B was observed during lactation in all groups. This may reflect an increase in the population of parity-influenced progenitor cells previously demonstrated to occur in murine mammary gland by Smith and colleagues (Wagner et al., 2002; Boulanger et al., 2005; Booth et al., 2007). Conversely, we noted a decrease in the proportion of mammary epithelial cells expressing NR5A2 and NUP153. For further discussion of MaSC or progenitor cells, parityinfluenced stem cells, and the markers employed in this study see Capuco et al. (2012), Capuco and Ellis (2013), and Choudhary et al. (2013). The validity of these putative markers, their association and localization throughout mammary development and the lactation cycle remains to be fully evaluated. Furthermore, the prevalence and distribution of MaSC and progenitor cells has not been fully evaluated in any species (Capuco et al., 2012). Nevertheless, the preponderance of evidence indicates that there was no effect of consuming endophyte-infected fescue seed on net growth and development of the mammary gland during the dry period. In seeming contrast to our results, an increase in proliferation rate of mammary epithelium of dry cows subjected to low plasma concentrations of PRL was noted, induced by exposure to a short photoperiod (Wall et al., 2005).

\section{Milk Production in the Final Lactation}

Our results demonstrate that endophyte-infected seed can be fed during the dry period without negatively affecting milk production in the next lactation. Despite decreased milk yield by INF and BROMO cows during the initial days of the final lactation (treatment was continued for the initial $10 \mathrm{~d}$ of this lactation), milk yield then increased so that the net yield for the lactation did not differ from CON. In agreement with our data, Bernard et al. (1993) reported that feeding endophyte-infected fescue grass during the final month before parturition did not reduce milk yield in the next lactation. Because they did not observe a reduction in feed intake and only a small decrease in PRL concentration relative to control (only significant at the time of parturition), consumption of ergot alkaloids was likely more moderate than that in our study. Both studies indicate that endophyte-infected fescue grass can be fed during the dry period without reducing milk production in the next lactation. Hence, we reject our initial hypothesis that feeding infected-fescue seed during the dry period decreases mammary development and subsequent milk yield.

Although milk yield in the subsequent lactation was not affected in INF cows, milk production was increased in BROMO cows. Bromocriptine is a brominated derivative of the natural ergot alkaloid, ergocryptine, and is a potent dopamine agonist. Additionally, it was administered at a dose that exceeded that of the ergot alkaloids consumed by the INF cows ( $~ 5$ fold; Table 2 ). The basal concentrations of PRL in the plasma were similarly reduced in INF and BROMO cows. However, the periparturient surge of plasma PRL was virtually eliminated in BROMO cows and markedly suppressed in INF cows. Differences in the effect of treatment on 
the milk yield may be attributed to many factors (dose, potency, DMI, body condition), but an important effect of the PRL surge at parturition must be considered.

\section{Speculation and Cautions}

Our experiment raises the possibility that appropriate utilization of endophyte-infected grasses can be used as a management tool in dairy production. Two timeframes may be targeted: the final days of lactation and the dry period.

Feeding endophyte-infected grasses during the final days of lactation would reduce milk production before dry off. This would be analogous to other dietary changes that are used to decrease milk production before dry off. As with other management schemes, this should enhance cow comfort and decrease the incidence of IMI at calving, as it has been established that at least a $77 \%$ increase exists in the incidence of IMI by environmental pathogens at calving for each $5 \mathrm{~kg}$ of milk yield above a threshold of $12.5 \mathrm{~kg}$ at dry off (Rajala-Schultz et al., 2005). Although we did not observe a significant increase in body temperature in INF cows, consumption of endophyte-infected grasses may decrease cow comfort during conditions of heat stress.

Conversely, feeding endophyte-infected grasses during the dry period can potentially increase profitability of dairying by reducing feed costs without reducing milk yield in the subsequent lactation. However, beyond utilizing this potential feed resource, is it possible that feeding endophyte-infected grasses may actually increase milk production in the next lactation? Mechanistically, this might be analogous to the increased milk production obtained when cows are subjected to short day length during the dry period (Auchtung et al., 2005; Wall et al., 2005), an effect that may be mediated by reducing PRL during the dry period and subsequently enhancing its activity during the ensuing lactation when day length was increased. In the current experiment, milk production was $\sim 9 \%$ greater in BROMO cows than CON cows after an initial period of depressed secretion; similarly, we noted a numerical, but nonsignificant, increase in INF cows. Thus, even when dry cows consumed endophyte-infected fescue seed at the same dose that significantly reduced milk yield during an established lactation, milk yield in the subsequent lactation was not reduced and actually trended toward increased production. Had we not continued treatment during the initial $(10 \mathrm{~d})$ period of lactation, or discontinued INF treatment before parturition, might milk production have increased from the outset of the subsequent lactation? Similar to results of the current study, when cows were treated with a dopamine antagonist for $12 \mathrm{~d}$ before parturition and the first $10 \mathrm{~d}$ or the ensuing lactation, milk yield was depressed during the treatment period, but was recovering by d 10 postcalving (Akers et al., 1981a). Management during early lactation can produce effects on milk yield that persist throughout lactation, as is the case for altered milking frequency (Bar-Peled et al., 1995; Hale et al., 2003). It remains to be determined if feeding endophyte-infected seed during early lactation partially countered a positive effect of treatment during the dry period in INF cows.

Before incorporating ergot-infected fescue grass into a dietary management scheme, one must consider potential effects on consumer health and animal health, which were not addressed by our study and remain to be fully investigated. The transfer of ergot alkaloids and other endophyte metabolites into marketable milk is an important concern. Current management of lactating dairy cows permits grazing on endophyte-infected pastures. The quantity of endophyte ergot alkaloids consumed by grazing cows will be a function of many factors including the endophyte, the grass cultivar and its maturity, seasonal conditions, and grazing selectivity. Transfer of ergot alkaloids to milk was evaluated in lactating dairy cows fed concentrations of endophyteinfected feed that equated to consumption of 4.2 to $16.3 \mu \mathrm{g}$ of alkaloids $/ \mathrm{kg}$ of BW (Schumann et al., 2009), dosages that extend beyond those employed in the current study. No ergot alkaloid residues were detected in blood or milk samples. The alkaloids were largely metabolized in the gastrointestinal tract and $\sim 24 \%$ were excreted in the feces. Whether future investigations employing more sensitive chemical analyses will reveal low concentrations of ergot metabolites in milk remains to be determined, as does an assessment of what might constitute a safe level for the most sensitive individuals in the human population. Treating cows during the dry period, may offer even less chance of transfer to milk during the next lactation, and incorporation of a withdrawal period of appropriate length can offer additional safety. Because plasma PRL concentrations rebound within 1 to $2 \mathrm{wk}$, a withdrawal period of this length is probably suitable. With lower levels of ergot consumption, the withdrawal period can likely be shorter.

Consequences of feeding endophyte-infected fescue seed or forage on animal health must also be considered. Fescue toxicosis can exert several health complications on the cow, particularly during heat stress, and the long-term effects of repeated usage should be considered. Health parameters were not sufficiently evaluated in the current study to draw conclusions. However, there were no significant changes in body temperature and gestation length in the INF group. We found shortterm changes in plasma indicators of birth stress in newborn calves, but no long-term effects (Kahl et al., 
2012). Monitoring cows in our study did not reveal any treatment-related health issues; however, effects of consuming endophyte-infected fescue grass over repeated lactation cycles remains to be fully evaluated for intensive management as well as pasture management.

Because endophyte-grass interactions influence forage and pasture sustainability, these grasses may be increasingly important forages in the face of global climate warming. Development and utilization of grasses infected with a novel endophyte that enhances pasture sustainability without deleterious effects on cattle is of considerable interest. The genetic mechanisms mediating the diverse effects of consuming the currently prevalent endophyte-infected fescue grasses, as observed in the current study, are the focus of an ongoing investigation utilizing RNA-sequencing to assess mammary gene expression.

\section{CONCLUSIONS}

Feeding endophyte-infected fescue seed decreased milk production during lactation, but its consumption during the dry period did not impair mammary development or milk production in the following lactation. Treatment with bromocriptine during the dry period increased milk production in the next lactation.

\section{ACKNOWLEDGMENTS}

The authors thank Donald Carbaugh and Dennis Hucht (Animal Genomics and Improvement Laboratory, USDA-ARS, Beltsville) for their excellent assistance with tissue sampling, feed preparation and animal handling, and Mary Niland (Animal Genomics and Improvement Laboratory, USDA-ARS, Beltsville) for technical assistance. We also thank personnel of the Beltsville Agricultural Research Center (Beltsville, MD) animal services, particularly Jonathan Leith and Mike Kemp for their help initiating the project and for managing cows throughout the study. This work was funded by Current Research Information Service project no. 1265-3200-083-00D from USDA Agricultural Research Service (Beltsville Agricultural Research Center), by National Research Initiative Competitive Grant no. 2008-35206-18825 from the USDA National Institute of Food and Agriculture (Beltsville Agricultural Research Center), and by University of Kentucky Agriculture Experiment Station (Manuscript No. 16-07-021).

\section{REFERENCES}

Aiken, G. E., B. H. Kirch, J. R. Strickland, L. P. Bush, M. L. Looper, and F. N. Schrick. 2007. Hemodynamic responses of the caudal artery to toxic tall fescue in beef heifers. J. Anim. Sci. 85:2337-2345.
Aiken, G. E., and J. R. Strickland. 2013. Forages and pastures symposium: managing the tall fescue-fungal endophyte symbiosis for optimum forage-animal production. J. Anim. Sci. 91:2369-2378.

Aiken, G. E., J. R. Strickland, M. L. Looper, L. P. Bush, and F. N. Schrick. 2009. Hemodynamics are altered in the caudal artery of beef heifers fed different ergot alkaloid concentrations. J. Anim. Sci. 87:2142-2150.

Akers, R. M., D. E. Bauman, A. V. Capuco, G. T. Goodman, and H. A. Tucker. 1981a. Prolactin regulation of milk secretion and biochemical differentiation of mammary epithelial cells in periparturient cows. Endocrinology 109:23-30.

Akers, R. M., D. E. Bauman, G. T. Goodman, A. V. Capuco, and H. A. Tucker. 1981b. Prolactin regulation of cytological differentiation of mammary epithelial cells in periparturient cows. Endocrinology 109:31-40.

Auchtung, T. L., A. G. Rius, P. E. Kendall, T. B. McFadden, and G. E. Dahl. 2005. Effects of photoperiod during the dry period on prolactin, prolactin receptor, and milk production of dairy cows. J. Dairy Sci. 88:121-127.

Bar-Peled, U., E. Maltz, I. Bruckental, Y. Folman, Y. Kali, H. Gacitua, A. R. Lehrer, C. H. Knight, B. Robinzon, H. Voet, and H. Tagari. 1995. Relationship between frequent milking or suckling in early lactation and milk production of high producing dairy cows. J. Dairy Sci. 78:2726-2736.

Bernard, J. K., A. B. Chestnut, B. H. Erickson, and F. M. Kelly. 1993 Effects of prepartum consumption of endophyte-infected tall fescue on serum prolactin and subsequent milk production of Holstein cows. J. Dairy Sci. 76:1928-1933.

Booth, B. W., C. A. Boulanger, and G. H. Smith. 2007. Alveolar progenitor cells develop in mouse mammary glands independent of pregnancy and lactation. J. Cell. Physiol. 212:729-736.

Boulanger, C. A., K. U. Wagner, and G. H. Smith. 2005. Parity-induced mouse mammary epithelial cells are pluripotent, self-renewing and sensitive to TGF-beta1 expression. Oncogene 24:552-560.

Brown, M. A., L. M. Tharel, A. H. Brown Jr., W. G. Jackson, and J. R. Miesner. 1993. Milk production in Brahman and Angus cows on endophyte-infected fescue and common bermudagrass. J. Anim. Sci. 71:1117-1122.

Capuco, A. V., R. M. Akers, and J. J. Smith. 1997. Mammary growth in Holstein cows during the dry period: quantification of nucleic acids and histology. J. Dairy Sci. 80:477-487.

Capuco, A. V., R. K. Choudhary, K. M. Daniels, R. W. Li, and C. M. Evock-Clover. 2012. Bovine mammary stem cells: Cell biology meets production agriculture. Animal 6:382-393.

Capuco, A. V., S. Ellis, D. L. Wood, R. M. Akers, and W. Garrett 2002. Postnatal mammary ductal growth: Three-dimensional imaging of cell proliferation, effects of estrogen treatment, and expression of steroid receptors in prepubertal calves. Tissue Cell $34: 143-154$

Capuco, A. V., and S. E. Ellis. 2013. Comparative aspects of mammary gland development and homeostasis. Annu. Rev. Anim. Biosci. $1: 179-202$

Capuco, A. V., D. L. Wood, R. Baldwin, K. McLeod, and M. J. Paape. 2001. Mammary cell number, proliferation, and apoptosis during a bovine lactation: relation to milk production and effect of bST. J. Dairy Sci. 84:2177-2187.

Chalkley, H. W. 1943. Method for the quantitative morphologic analysis of tissues. J. Natl. Cancer Inst. 4:47-53.

Choudhary, R. K., and A. V. Capuco. 2012. In vitro expansion of the mammary stem/progenitor cell population by xanthosine treatment. BMC Cell Biol. 13:14.

Choudhary, R. K., R. W. Li, C. M. Evock-Clover, and A. V. Capuco. 2013. Comparison of the transcriptomes of long-term label retaining-cells and control cells microdissected from mammary epithelium: An initial study to characterize potential stem/progenitor cells. Front. Oncol. 3:21.

Crawford, H. M., D. E. Morin, E. H. Wall, T. B. McFadden, and G. E. Dahl. 2015. Evidence for a role of prolactin in mediating effects of photoperiod during the dry period. Animals (Basel) 5:803-820. 
Farr, V. C., K. Stelwagen, L. R. Cate, A. J. Molenaar, T. B. McFadden, and S. R. Davis. 1996. An improved method for the routine biopsy of bovine mammary tissue. J. Dairy Sci. 79:543-549.

Finucane, K. A., T. B. McFadden, J. P. Bond, J. J. Kennelly, and F. Q. Zhao. 2008. Onset of lactation in the bovine mammary gland: Gene expression profiling indicates a strong inhibition of gene expression in cell proliferation. Funct. Integr. Genomics 8:251-264.

Fitzgerald, B. P., and F. J. Cunningham. 1982. Effects of metoclopramide and bromocriptine on prolactin secretion in the pregnant ewe. J. Endocrinol. 93:41-46.

Forrest, D. W., J. L. Fleeger, C. R. Long, A. M. Sorensen Jr., and P. G. Harms. 1980. Effect of exogenous prolactin on peripheral luteinizing hormone levels in ovariectomized cows. Biol. Reprod. 22:197-201.

Gundel, P. E., M. A. Martinez-Ghersa, M. Omacini, R. Cuyeu, E. Pagano, R. Rios, and C. M. Ghersa. 2012. Mutualism effectiveness and vertical transmission of symbiotic fungal endophytes in response to host genetic background. Evol. Appl. 5:838-849.

Hale, S. A., A. V. Capuco, and R. A. Erdman. 2003. Milk yield and mammary growth effects due to increased milking frequency during early lactation. J. Dairy Sci. 86:2061-2071.

Kahl, S., T. H. Elsasser, R. L. Baldwin, A. V. Capuco, P. Grossi, and K. R. McLeod. 2012. Effects of feeding endophyte-infected fescue seed to Holstein cows during the dry period on plasma nitric oxide $(\mathrm{NO})$, xanthine oxidase $(\mathrm{XO})$ and haptoglobin $(\mathrm{Hp})$ status in newborn calves. J. Anim. Sci. 90(Suppl. 3):508. (Abstr.)

Lacasse, P., V. Lollivier, F. Dessauge, R. M. Bruckmaier, S. Ollier, and M. Boutinaud. 2012. New developments on the galactopoietic role of prolactin in dairy ruminants. Domest. Anim. Endocrinol. 43:154-160.

Peters, C. W., K. N. Grigsby, C. G. Aldrich, J. A. Paterson, R. J. Lipsey, M. S. Kerley, and G. B. Garner. 1992. Performance, forage utilization, and ergovaline consumption by beef cows grazing endophyte fungus-infected tall fescue, endophyte fungus-free tall fescue, or orchardgrass pastures. J. Anim. Sci. 70:1550-1561.

Rajala-Schultz, P. J., J. S. Hogan, and K. L. Smith. 2005. Short communication: Association between milk yield at dry-off and probability of intramammary infections at calving. J. Dairy Sci. 88:577-579.

Schneider, C. A., W. S. Rasband, and K. W. Eliceiri. 2012. NIH Image to ImageJ: 25 years of image analysis. Nat. Methods 9:671-675.

Schumann, B., P. Lebzien, K. H. Ueberschar, and S. Danicke. 2009. Effects of the level of feed intake and ergot contaminated concentrate on ergot alkaloid metabolism and carry over into milk. Mol. Nutr. Food Res. 53:931-938.

Stamm, M. M., T. DelCurto, M. R. Horney, S. D. Brandyberry, and R. K. Barton. 1994. Influence of alkaloid concentration of tall fescue straw on the nutrition, physiology, and subsequent performance of beef steers. J. Anim. Sci. 72:1068-1075.

Strickland, J. R., J. W. Oliver, and D. L. Cross. 1993. Fescue toxicosis and its impact on animal agriculture. Vet. Hum. Toxicol. $35: 454-464$.

Wagner, K. U., C. A. Boulanger, M. D. Henry, M. Sgagias, L. Hennighausen, and G. H. Smith. 2002. An adjunct mammary epithelial cell population in parous females: Its role in functional adaptation and tissue renewal. Development 129:1377-1386.

Wall, E. H., T. L. Auchtung, G. E. Dahl, S. E. Ellis, and T. B. McFadden. 2005. Exposure to short day photoperiod during the dry period enhances mammary growth in dairy cows. J. Dairy Sci. 88:1994-2003.

Wood, P. D. P. 1967. Algebraic model of the lactation curve in cattle. Nature 216:164-165.

Wood, P. D. P. 1969. Factors affecting the shape of the lactation curve in cattle. Anim. Prod. 11:307-316. 